\title{
Nosocomial tuberculosis prevention in Portuguese hospitals: a cross-sectional evaluation
}

\author{
M. Sousa, ${ }^{*}$ M. Gomes, ${ }^{\dagger \neq}$ A. R. Gaio, ${ }^{\text {\$ा R. Ruarte }}{ }^{\dagger \neq \# * *}$ \\ *Centro Hospitalar Tondela-Viseu, Porto, ${ }^{+}$Centro Hospitalar de Vila Nova de Gaia/Espinho, Vila Nova de Gaia, \\ "EPIUnit Institute of Public Health, \$Mathematics Department, Faculty of Sciences, and "Centre of Mathematics, \\ University of Porto, Porto, "Chest Disease Centre, Vila Nova de Gaia, **Department of Clinical Epidemiology, \\ Predictive Medicine and Public Health, University of Porto Medical School, Porto, Portugal
}

S U M M A R Y

SETTING: Measures to control tuberculous infection are crucial to prevent nosocomial transmission and protect health care workers (HCWs). In Portugal, the extent of implementation of tuberculosis (TB) control measures in hospitals is not known.

OBJECTIVE: To determine the current implementation of preventive measures for tuberculous infection at administrative, environmental and personal levels in Portuguese hospitals.

DESIGN: A cross-sectional evaluation was performed using two anonymous questionnaires: one sent to all the hospital infection control (IC) committees and the other sent to all pulmonologists and physicians specialising in infectious disease.

RESULTS: Fourteen IC committees and 72 physicians responded. According to the IC committees, $92 \%$ of hospitals had a written TB control plan, but only $37 \%$ of the physicians said there was always/almost always a fast track for diagnosing suspected pulmonary TB cases. The majority of the hospitals had an isolation policy $(85 \%)$ and these patients were always/almost always admitted in separate rooms, according to $70 \%$ of physicians. Both HCWs and TB patients used respiratory protection equipment $(92 \%)$.

CONCLUSION: These findings indicate that the most basic TB IC measures had been undertaken, but some TB IC measures were not fully implemented at all hospitals. An institutional effort should be made to solve this problem and strengthen TB prevention activities. KEY WORDS: nosocomial infection; prevention; TB
TUBERCULOSIS (TB) IS A MAJOR cause of morbidity and mortality in many countries and a significant health problem worldwide. According to the World Health Organization (WHO), there were more than 9 million new TB cases and approximately 1.5 million deaths due to TB in $2014 .{ }^{1}$ In Portugal, TB incidence in 2014 was 20 new cases per 100000 population. Despite reductions in recent years, Portugal still has one of the highest TB incidence rates among European Union countries. ${ }^{2}$

Health care workers (HCWs) are at particularly high risk of tuberculous infection due to frequent exposure to patients with active pulmonary TB. The risk of TB transmission in hospital personnel is 2-10 times higher than among the general population. ${ }^{3}$ The risk of exposure to TB is thought to be higher in pulmonology/infectious disease wards due to the larger number of contagious patients managed in these wards. ${ }^{4}$

To prevent TB transmission in health care settings, the US Centers for Disease Control and Prevention (CDC) and the WHO have recommended several infection control (IC) measures and prevention programmes. ${ }^{5,6}$ These programmes are based on a three-level hierarchy of control measures, involving administrative controls, environmental controls and the use of respiratory protective equipment. Administrative controls affect the largest number of people and are intended primarily to reduce the risk of exposure among non-infected people. Environmental controls are designed to prevent the spread and reduce the concentration of infectious droplet nuclei in ambient air. Use of respiratory protection equipment can further reduce the risk of exposure among HCWs to infectious droplet nuclei that have been expelled into the air from a patient with infectious TB. $^{5}$

However, despite these measures, nosocomial TB outbreaks continue to occur in many countries. ${ }^{7-9}$ In Portugal, high levels of active TB in HCWs have been reported. For example, a descriptive study of active TB cases identified in occupational health screening between 2005 and 2010 found that 62 of the 6112 HCWs evaluated had active TB. ${ }^{10}$ These findings emphasise the importance of information regarding the implementation of $\mathrm{TB}$ infection prevention

Correspondence to: Marta Sousa, Centro Hospitalar Tondela-Viseu, Rua S João 42, Tamel S Veríssimo, 4750-745 Barcelos, Portugal. e-mail: martadias.sousa@gmail.com

Article submitted 15 November 2016. Final version accepted 22 April 2017. 
Table 1 Administrative and environmental measures according to infection control committees

\begin{tabular}{|c|c|c|c|}
\hline Administrative measures & $\begin{array}{c}\text { Yes } \\
n(\%)\end{array}$ & $\begin{array}{c}\text { No } \\
n(\%)\end{array}$ & $\begin{array}{c}\text { No answer } \\
n(\%)\end{array}$ \\
\hline Existence of a written TB control plan & $13(93)$ & $1(7)$ & - \\
\hline Education for HCW about TB & $12(86)$ & $2(14)$ & - \\
\hline Regular meetings to evaluate TB control plan implementation & $7(50)$ & $7(50)$ & - \\
\hline Separate rooms for TB patients & $12(86)$ & - & $2(14)$ \\
\hline Existence of an antechamber in the separate rooms & $9(64)$ & $5(36)$ & - \\
\hline \multicolumn{4}{|l|}{ Environmental measures } \\
\hline Negative pressure in the separate rooms & $7(50)$ & $7(50)$ & - \\
\hline Presence of high-efficiency particulate air filtration to clean the air in separate rooms & $8(57)$ & $6(43)$ & - \\
\hline
\end{tabular}

$\mathrm{TB}=$ tuberculosis; $\mathrm{HCW}=$ health care worker.

measures in every country, allowing governments and health care associations to provide appropriate support and enabling hospitals to follow recommended guidelines.

In Portugal, the extent of the implementation of TB control measures in hospitals is not known. The present study was conducted to determine current TB preventive measures at all levels in Portuguese hospitals, obstacles to implementation of TB preventive measures, and the needs of hospitals to improve TB prevention activities.

\section{STUDY POPULATION AND METHODS}

Data were collected using two anonymous questionnaires developed by the researchers of the study and made available online from January to May 2016. The first questionnaire, which collected data on administrative and environmental measures, was sent out by e-mail to all hospital IC committees. The second questionnaire, which collected data on the daily application of all three levels of TB prevention measures (administrative measures, environmental measures and use of respiratory protection equipment) was e-mailed to all pulmonologists and specialists in infection disease through their societies: Sociedade Portuguesa de Pneumologia, Lisbon, and Sociedade Portuguesa de Infecciologia, Lisbon, Portugal, respectively. Responses to the questionnaires were analysed descriptively. Categorical data were described in percentages and numbers.

The Ethics Committee of the Institute of Public Health/University of Porto, Porto, Portugal, approved the study protocol.

\section{RESULTS}

\section{Questionnaire answered by infection control committees}

Of 40 hospital IC committees contacted, 14 responded to the first questionnaire (Table 1). Although $92 \%$ of these hospitals had a written TB control plan, only $54 \%$ used regular audits to evaluate the efficiency of their TB prevention system. In addition, $85 \%$ of the hospitals provided HCWs with training on the prevention of TB transmission within the hospital. Assessments of TB isolation policies found that $85 \%$ of responding hospitals had separate rooms for patients with $\mathrm{TB}$, with $50 \%$ of isolation rooms having negative pressure and $57 \%$ having control measures such as high-efficiency particulate air (HEPA) filters to reduce the concentration of droplet nuclei in adjacent areas.

\section{Questionnaire answered by pulmonologists/infectious} disease physicians

The second questionnaire, designed to evaluate the implementation of $\mathrm{TB}$ prevention measures at all levels, was answered by 72 of a total 910 physicians (Tables 2 and 3). In managing patients with suspected or confirmed TB, $37 \%$ of these physicians reported that there was always or almost always a fast track for diagnosing suspected pulmonary TB patients, with priority given to observation and examinations. In addition, $83 \%$ of the physicians reported that sputum was collected from these patients within the first few hours after hospital admission.

According to $70 \%$ of physicians, patients with suspected or confirmed TB were always or almost always admitted to separate rooms. In addition, $84 \%$ of physicians reported that the doors of these separate rooms were always or almost always closed. Only $18 \%$ of physicians said that invasive respiratory examinations were performed in rooms with negative pressure. Of the physicians who responded, $73 \%$ reported that information regarding respiratory protection measures was always or almost always posted on the doors of these rooms. In addition, $78 \%$ of physicians reported that these patients were always or almost always allowed visitors, and $83 \%$ reported that education regarding TB prevention measures was always or almost always provided to these visitors.

With regard to environmental measures, 29\% of physicians answered that these isolation rooms had natural ventilation, $58 \%$ responded that these rooms had negative pressure and $11 \%$ said they had control measures, such as HEPA filters, to reduce the concentration of droplet nuclei in adjacent areas; $1 \%$ of physicians did not respond to this question. Of 
Table 2 Implementation of TB control measures in hospitals according to pulmonologists and infection disease physicians

\begin{tabular}{|c|c|c|c|c|}
\hline Implementation of infection control measures & $\begin{array}{l}\text { Always/almost always } \\
\qquad n(\%)\end{array}$ & $\begin{array}{l}\text { Sometimes } \\
n(\%)\end{array}$ & $\begin{array}{l}\text { Never } \\
n(\%)\end{array}$ & $\begin{array}{l}\text { No answer } \\
n(\%)\end{array}$ \\
\hline \multicolumn{5}{|l|}{ Administrative measures } \\
\hline $\begin{array}{l}\text { Priority evaluation in the emergency room for patients with } \\
\text { confirmed/suspected TB }\end{array}$ & $27(38)$ & $30(42)$ & $15(20)$ & - \\
\hline Prompt sputum collection in patients with suspected TB & $60(83)$ & $9(13)$ & $2(3)$ & $1(1)$ \\
\hline Patients with confirmed/suspected TB admitted to separate rooms & $51(71)$ & $11(15)$ & $5(7)$ & $5(7)$ \\
\hline Closed door policy in the separate rooms for TB patients & $61(85)$ & $3(4)$ & - & $8(11)$ \\
\hline $\begin{array}{l}\text { Written information regarding respiratory protection on the door of } \\
\text { TB patient rooms }\end{array}$ & $53(74)$ & $8(11)$ & $2(3)$ & $9(13)$ \\
\hline Visits allowed for patients with suspected/confirmed TB & $56(78)$ & $13(18)$ & $1(1)$ & $2(3)$ \\
\hline Information regarding TB protection measures given to visitors & $60(83)$ & $8(11)$ & $1(1)$ & $3(4)$ \\
\hline \multicolumn{5}{|l|}{ Environmental measures* } \\
\hline $\begin{array}{l}\text { Invasive respiratory examinations (bronchoscopy) performed in } \\
\text { separate rooms with negative pressure }\end{array}$ & $13(18)$ & $12(17)$ & $45(63)$ & $2(3)$ \\
\hline \multicolumn{5}{|l|}{ Use of respiratory protection } \\
\hline $\begin{array}{l}\text { Respiratory protection mask use by patients with suspected/ } \\
\text { confirmed respiratory TB upon admission }\end{array}$ & $66(92)$ & $6(8)$ & - & - \\
\hline $\begin{array}{l}\text { Protection mask use by patients with suspected respiratory TB during } \\
\text { movement within the hospital }\end{array}$ & $64(89)$ & $7(10)$ & - & $1(1)$ \\
\hline $\begin{array}{l}\text { Protection mask use by HCWs when in direct contact with confirmed } \\
\text { TB patients/patients with suspected TB }\end{array}$ & $66(92)$ & $5(7)$ & - & $1(1)$ \\
\hline $\begin{array}{l}\text { Protection mask use by HCWs when performing procedures } \\
\text { involving airborne risk (bronchoscopy, intubation) in confirmed TB } \\
\text { patients/patients with suspected TB }\end{array}$ & $67(93)$ & $2(3)$ & - & $3(4)$ \\
\hline
\end{tabular}

* Specific questions regarding environmental measures with other answer options are described in the text.

$\mathrm{TB}=$ tuberculosis; $\mathrm{HCW}=$ health care worker.

the physicians who responded that their patients with suspected or confirmed TB were never admitted to separate rooms in their hospitals, $80 \%$ reported that they were admitted to regular (non-isolation) rooms wearing respiratory protection masks. The other $20 \%$ did not specify the measures applied to these patients.

According to $91 \%$ of physicians, patients with suspected or confirmed respiratory $\mathrm{TB}$ always or almost always wore respiratory protection equipment, and HCWs always or almost always used respiratory protection equipment when in direct contact with these patients. Patients most often used simple face masks $(51 \%)$, whereas HCWs most often used N95 masks (87\%) (Table 3). According to $88 \%$ of physicians, patients with suspected or confirmed respiratory $\mathrm{TB}$ wore respiratory protection equipment while being transported within the hospital, $52 \%$ of whom wore N95 masks. In addition, $95 \%$ of physicians reported always or almost always using respiratory protection equipment when performing procedures that involved an airborne risk (e.g., bronchoscopy, intubation) on patients with suspected or confirmed respiratory TB.

\section{DISCUSSION}

The present study evaluated the implementation and practice of TB IC measures in Portuguese hospitals using online anonymous questionnaires sent out to IC committees, pulmonologists and infectious disease specialists. Study findings suggested that hospitals had initiated the most basic TB IC measures, but that some TB IC measures were not fully implemented in all hospitals.

Comprehensive implementation of TB preventive measures emphasises administrative control, environmental control and respiratory protection. All of these activities can substantially reduce or eliminate transmission of TB. ${ }^{5}$ Administrative control measures are the first and most important level of control for the reduction of exposure among HCWs and other patients to TB. The results of this study revealed that most hospitals implemented administrative control measures. Ac-

Table 3 Type of respiratory protection masks used in different situations

\begin{tabular}{|c|c|c|c|c|c|}
\hline Conditions & $\begin{array}{c}\text { Simple face } \\
\text { masks } \\
n(\%)\end{array}$ & $\begin{array}{c}\mathrm{P} 1 \text { masks } \\
n(\%)\end{array}$ & $\begin{array}{c}\text { N95/FFP2 } \\
\text { masks } \\
n(\%)\end{array}$ & $\begin{array}{c}\text { Unknown } \\
n(\%)\end{array}$ & $\begin{array}{c}\text { No answer } \\
n(\%)\end{array}$ \\
\hline Patients with suspected/confirmed TB at admission & $37(51)$ & $3(4)$ & $30(42)$ & $1(1)$ & $1(1)$ \\
\hline HCWs when in direct contact with suspected/confirmed TB patients & $4(6)$ & $3(4)$ & $62(86)$ & - & $3(4)$ \\
\hline $\begin{array}{l}\text { Patients with suspected/confirmed TB during movement transport } \\
\text { within the hospital }\end{array}$ & $30(42)$ & $3(4)$ & $38(53)$ & - & $1(1)$ \\
\hline
\end{tabular}

$\mathrm{TB}=$ tuberculosis; $\mathrm{HCW}=$ health care worker. 
cording to the IC committees of the responding hospitals, most $(93 \%)$ had written TB control plans, although only $50 \%$ regularly evaluated their daily implementation. These hospitals had established policies for the isolation of patients with confirmed/suspected TB, with $86 \%$ providing separate rooms for such patients. In addition, $86 \%$ provided education to HCWs about TB. However, only $38 \%$ of physicians said that hospitals always provided a fast track for the evaluation of these patients, $83 \%$ reported that they always collected sputum during the first few hours after hospital admission and $71 \%$ said that these patients were always admitted to separate rooms. These policies reflect the importance to hospital administrations of preventing TB transmission. However, successful prevention requires that these measures be extended to all hospitals.

Protocols for the isolation of patients with suspected TB are among the most effective control measures for the prevention of nosocomial transmission of this disease. ${ }^{11}$ However, some hospitals (14\%) still do not provide separate rooms for these patients. In addition, the majority of patients with suspected/confirmed TB were not promptly evaluated upon hospital admission. This can delay the identification of patients with infectious TB and facilitate transmission. Rapid screening of patients with suspected TB on admission is a rapid, low-cost activity that helps prevent the spread of TB to other patients and HCWs and should be implemented in every hospital. Another problem identified in our study was that only half of the hospitals assessed the implementation of these measures. Audits to evaluate compliance with these guidelines are crucial, and should be regular practice.

The second step of prevention is environmental control, which aims to prevent the spread and reduce the concentration of Mycobacterium tuberculosis in ambient air by using ventilation systems. As recommended by the US CDC, high-risk areas should have negative pressure, and air ventilated to other areas of the hospital should be cleaned using HEPA filters and, if necessary, ultraviolet germicidal irradiation. ${ }^{12}$ We found that only $50 \%$ of hospitals had negative pressure systems in the isolation rooms for TB patients, and only $57 \%$ had HEPA filtration to clean the air. Moreover, in $63 \%$ of hospitals, bronchoscopy was never performed in separate rooms with negative pressure.

Our results are in agreement with other studies that have reported problems with the isolation of TB patients and ventilation of hospital rooms. For example, a study evaluating the prevention of nosocomial TB in hospitals in Thailand reported that $80 \%$ of hospitals $(n=524)$ had an insufficient number of isolation rooms, with approximately one third having poor ventilation in these isolation rooms. ${ }^{13}$ Another study that assessed nosocomial $\mathrm{TB}$ in $\mathrm{China}^{14}$ found that only $46 \%$ of TBdesignated hospitals $(n=88)$ segregated patients with suspected TB.

Although we found some inadequacies in the ventilation of rooms for TB patients, we only evaluated secondary measures, which are an effective but expensive complement. Our questionnaires did not include questions about the use of primary environmental measures, such as natural ventilation, which can be cost-effective in some cases. ${ }^{15}$

Personal respiratory protection is the third recommended measure to protect $\mathrm{HCW}$, other patients and visitors from inhaling infectious droplets. Guidelines recommend that HCWs and visitors should use FFP2/ N95 masks if there is a high risk of TB transmission. ${ }^{12,16}$ Simple surgical face masks are not considered individual protection equipment for these groups and are reserved for $\mathrm{TB}$ patients to minimise direct transmission of exhaled bacteria to the environment. ${ }^{16}$ Individual protection masks with filtration systems, such as P1 masks, are less effective than FFP2/N95 masks in filtering particles $(80 \%$ vs. $94 \%) .{ }^{17}$

In our study, $92 \%$ of physicians reported that patients with suspected respiratory TB used respiratory protection masks upon hospital admission, with $51 \%$ using simple face masks. According to $92 \%$ of physicians, respiratory protection masks were used by HCWs when in direct contact with TB patients, with $86 \%$ using N95/FFP2 masks. These results suggest that most hospitals use personal respiratory protection correctly, although only $46 \%$ of TB patients used a particle respirator mask rather than a simple face mask, as recommended, as the latter may be less expensive.

These findings suggest some important problems and needs, mainly related to rapid screening and isolation of TB patients and the use of good ventilation systems to prevent the spread of TB. The type of respiratory protection equipment used by patients was also not standardised. Finally, although most hospitals have institutional guidelines, only $50 \%$ of hospitals evaluate compliance with these measures. Because the risk of nosocomial infection is present in all hospitals, and Portugal still has one of the highest TB incidence rates among European Union countries, efforts are needed to fully implement TB control measures and resolve the needs and problems of these hospitals.

Our study had limitations associated mainly with its design and approach to data collection. We used an anonymous questionnaire, which is not a validated data collection tool, and it is not clear how much these online self-administered questionnaires can describe the reality of IC conditions in hospitals. Conversely, by using an easy, readily available and anonymous tool, we could reach a wider number of 
participants and evaluate the real-life application of these measures as assessed by each physician.

\section{CONCLUSION}

The main objective of the study was to evaluate the implementation and practice of TB IC measures in Portuguese hospitals using two online questionnaires. We observed that responding hospitals had instituted the most basic TB IC measures. However, some TB IC measures were not fully implemented in all hospitals, emphasising the need for a nationwide effort to solve this problem and strengthen TB prevention activities. Our study nevertheless had some limitations with regard to data collection, and did not evaluate other important aspects of TB prevention, such as screening hospital personnel for tuberculous infection. Additional studies are required to fully understand nosocomial TB in Portugal.

\section{Acknowledgements}

The authors would like to thank all the designated hospital IC committees, pulmonologists and infection disease specialists for their participation; the Sociedade Portuguesa de Pneumologia, Lisbon, and Sociedade Portuguesa de Infecciologia Lisbon, Portugal, for their support in e-mailing the questionnaires. Conflicts of interest: none declared.

\section{References}

1 World Health Organization. Global tuberculosis report, 2015. WHO/HTM/TB/2015.22. Geneva, Switzerland: WHO, 2015.

2 Direção Geral de Saúde. Portugal-Infeção por VIH, SIDA e Tuberculose em números. Lisbon, Portugal: Direção Geral de Saúde, 2015. http://www.dgs.pt/?cr=291182015. Accessed April 2017.

3 Pugliese G, Tapper M L. Tuberculosis control in health care. Infect Control Hosp Epidemiol 1996; 17: 819-827.

4 Hsieh M J, Liang H W, Chiang P C, et al. Delayed suspicion, treatment and isolation of tuberculosis patients in pulmonology/infectious diseases and non-pulmonology/ infectious diseases wards. J Formos Med Assoc 2009; 108: 202-209.

5 Jensen P A, Lambert L A, Iademarco M F, Ridzon R. Guidelines for preventing the transmission of Mycobacterium tuberculosis in health-care settings, 2005. MMWR Recomm Rep 2005; 54(RR-17): 1-141.

6 World Health Organization. Guidelines for the prevention of tuberculosis in health care facilities in resource-limited settings. WHO/CDS/TB/99.269. Geneva, Switzerland: WHO, 1999.

7 Welbel S F, French A L, Bush P, DeGuzman D, Weinstein R A. Protecting health care workers from tuberculosis: a 10-year experience. Am J Infect Control 2009; 37: 668-673.

8 Escombe A R, Huaroto L, Ticona E, et al. Tuberculosis transmission risk and infection control in a hospital emergency department in Lima, Peru. Int J Tuberc Lung Dis 2010; 14: $1120-1126$.

9 Gandhi N R, Weissman D, Moodley P, et al. Nosocomial transmission of extensively drug-resistant tuberculosis in a rural hospital in South Africa. J Infect Dis 2013; 207: 9-17.

10 Costa J C, Silva R, Ferreira J, Nienhaus A. Active tuberculosis among health care workers in Portugal. J Bras Pneumol 2011; 37: 636-645.

11 LoBue P A, Catanzaro A. Effectiveness of a nosocomial tuberculosis control program at an urban teaching hospital. Chest 1998; 113: 1184-1189.

12 Centers for Disease Control and Prevention. Core curriculum on tuberculosis: what the clinician should know. Atlanta, GA, USA: CDC, 2013.

13 Unahalekhaka A, Lueang-a-papong S, Chitreecheur J. Status of nosocomial tuberculosis transmission prevention in hospitals in Thailand. Am J Infect Control 2014; 42: 340-343.

14 Chen B, Liu M, Gu H, et al. Implementation of tuberculosis infection control measures in designated hospitals in Zhejiang Province, China: are we doing enough to prevent nosocomial tuberculosis infections? BMJ Open 2016; 6: e010242.

15 Escombe A R, Oeser C C, Gilman R H, et al. Natural ventilation for the prevention of airborne contagion. PLOS Med 2007; 4: e68.

16 World Health Organization. Policy on TB infection control in health-care facilities, congregate settings and households. WHO/HTM/TB/2009.419. Geneva, Switzerland: WHO, 2009.

17 Health and Safety Executive. Respiratory protective devices: filtering half masks to protect against particles-Requirements, testing, marking. EN 149:2001+A1:2009. Bootle, UK: HSE, 2010 . 
CONTEXTE: Les mesures de lutte contre l'infection tuberculeuse sont cruciales pour prévenir la transmission nosocomiale et protéger les prestataires de soins de santé (HCW). Au Portugal, on ne connaît pas le degré de la mise en ouvre des mesures de lutte contre la tuberculose (TB) dans les hôpitaux.

OBJECTIF : Déterminer la mise en ouvre actuelle des mesures administratives, environnementales et personnelles de prévention de l'infection tuberculeuse dans les hôpitaux du Portugal.

SCHÉMA : Une évaluation transversale a été réalisée grâce à deux questionnaires anonymes, l'un envoyé à tous les comités de lutte contre les infections hospitalières et l'autre à tous les pneumologues et médecins de maladies infectieuses.

RÉSULTATS : Un total de 14 comités de lutte contre l'infection et 72 médecins ont répondu. Selon les comités de lutte contre l'infection, $\mathbf{9 2} \%$ des hôpitaux avaient un plan écrit de lutte contre la TB, mais seulement $37 \%$ des médecins ont déclaré qu'il y avait toujours/presque toujours une procédure rapide pour le diagnostic d'une suspicion de TB pulmonaire. La majorité des hôpitaux avaient une politique d'isolement $(85 \%)$ et ces patients ont été toujours/presque toujours admis dans des chambres séparées, selon $70 \%$ des médecins. A la fois les $\mathrm{HCW}$ et les patients TB ont fait usage d'équipements de protection respiratoire $(\mathbf{9 2} \%)$.

CONCLUSION : Ces résultats montrent que les mesures de protection les plus basiques de lutte contre l'infection tuberculeuse ont été entreprises, mais certaines mesures de lutte contre la TB n'ont pas été complètement mises en œuvre dans tous les hôpitaux. Un effort institutionnel est nécessaire pour résoudre ce problème et renforcer les activités de prévention de la TB.
MARCO DEREFERENCIA: Las medidas de control de la infección tuberculosa son esenciales con el fin de evitar la transmisión intrahospitalaria y proteger a los profesionales de salud (HCW). En Portugal, se desconoce la magnitud de aplicación de las medidas de control de la infección tuberculosa en los hospitales.

O B JETIV O: Determinar el grado de aplicación actual de las medidas administrativas, ambientales y personales de prevención de la infección tuberculosa en los hospitales portugueses.

MÉTODO: Se llevó a cabo una evaluación transversal mediante dos cuestionarios anónimos, uno enviado a todos los comités de control de infecciones (IC) de los hospitales y el otro, a todos neumólogos y los médicos especialistas en enfermedades infecciosas.

RESULTADOS: Se obtuvieron respuestas de 14 comités IC y de 72 médicos. Según los comités, el $\mathbf{9 2 \%}$ de los hospitales contaba con un plan escrito de control de la tuberculosis (TB), pero solo el $37 \%$ de los médicos afirmó que siempre o casi siempre existía una vía acelerada para el diagnóstico de los casos con presunción de TB pulmonar. La mayoría de los hospitales contaba con una política de aislamiento $(85 \%)$ y según el $70 \%$ de los médicos estos pacientes siempre o casi siempre se acogían en salas independientes. Los HCW y también los pacientes con presunción de TB utilizaban equipos personales de protección respiratoria $(92 \%)$.

CONCLUSIÓN: Los resultados de la encuesta indican que se han emprendido las medidas más elementales de IC tuberculosa, pero algunas no se aplican plenamente en todos los hospitales. Es importante realizar un esfuerzo institucional encaminado a solucionar estas carencias y fortalecer las actividades de prevención de la TB. 